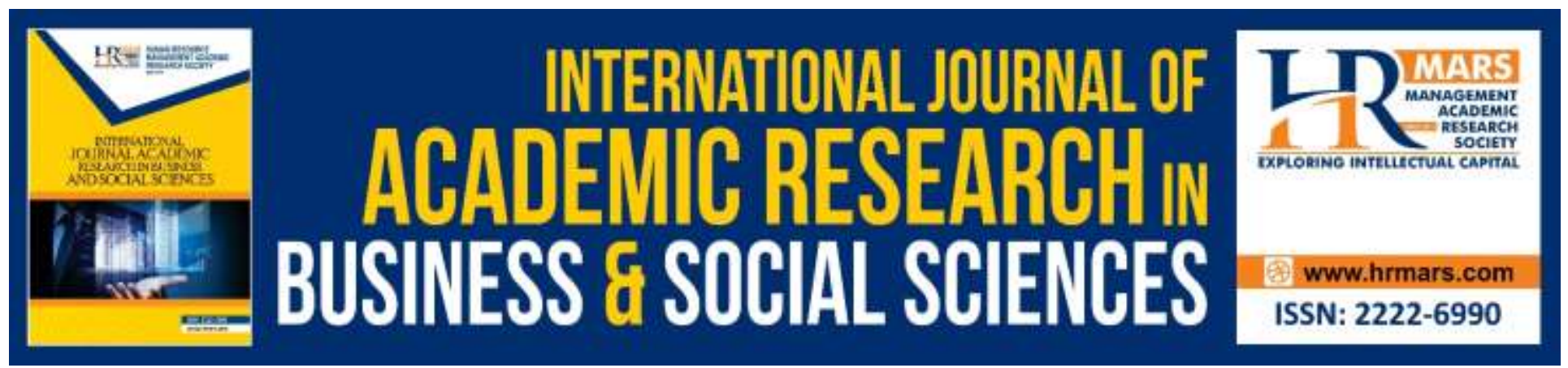

\title{
Can Greater Levels of Cooperation Help to Improve Productivity and Resilience in UK Agriculture Post Brexit Drawing Comparisons with the New Zealand Dairy Industry Experience?
}

Federico, G. Topolansky Barbe, Alex, Dunn, Magdalena, M. Gonzalez Triay

To Link this Article: http://dx.doi.org/10.6007/IJARBSS/v10-i2/6928

DOI:10.6007/IJARBSS/v10-i2/6928

Received: 13 January 2020, Revised: 28 January 2020, Accepted: 06 February 2020

Published Online: 20 February 2020

In-Text Citation: (Federico et al., 2020)

To Cite this Article: Federico, G. T. B., Alex, D., \& Magdalena, M. G. T. (2020). Can Greater Levels of Cooperation Help to Improve Productivity and Resilience in UK Agriculture Post Brexit Drawing Comparisons with the New Zealand Dairy Industry Experience? International Journal of Academic Research in Business and Social Sciences, 10(2), 277-293.

Copyright: (c) 2020 The Author(s)

Published by Human Resource Management Academic Research Society (www.hrmars.com)

This article is published under the Creative Commons Attribution (CC BY 4.0) license. Anyone may reproduce, distribute, translate and create derivative works of this article (for both commercial and non-commercial purposes), subject to full attribution to the original publication and authors. The full terms of this license may be seen

at: http://creativecommons.org/licences/by/4.0/legalcode

Vol. 10, No. 2, 2020, Pg. $277-293$

http://hrmars.com/index.php/pages/detail/IJARBSS

JOURNAL HOMEPAGE

Full Terms \& Conditions of access and use can be found at http://hrmars.com/index.php/pages/detail/publication-ethics 


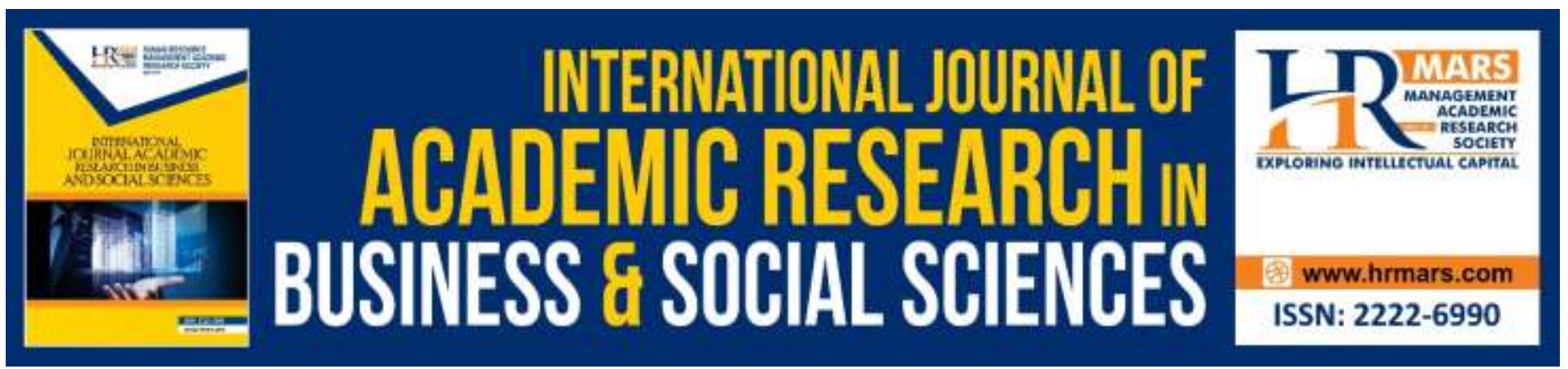

\title{
Can Greater Levels of Cooperation Help to Improve Productivity and Resilience in UK Agriculture Post Brexit Drawing Comparisons with the New Zealand Dairy Industry Experience?
}

\author{
Dr. Federico, G. Topolansky Barbe \\ Coventry University, Coventry Business School, CV1 5ED, United Kingdom
}

\begin{abstract}
Alex, Dunn
The Royal Agricultural University, School of Business and Entrepreneurship, GL7 6JS, United Kingdom
\end{abstract}

Magdalena, M. Gonzalez Triay

University of Gloucestershire, School of Business, GL50 2RH, United Kingdom

Email: ad3665@coventry.ac.uk, agrotopo@hotmail.com

\begin{abstract}
UK agriculture is being challenged to improve its productivity to secure its long-term resilience in the post Brexit era and to contribute to wider UK economic growth. Within this context, this paper has two main objectives: first, to identify opportunities and challenges facing UK agriculture in the postBrexit era; and second to assess the applicability of the New Zealand cooperative business model to the post-Brexit agriculture sector in the UK. This study uses a mixed methods research approach. Indepth personal interviews were carried out with UK and New Zealand industry experts. Quantitative data from UK farmers supplemented the core interviews. The results of this study indicate that whilst cooperatives had the potential to add great strength to the UK agricultural industry, they were not the only solution. Findings have revealed that effective collaboration will be dependent on a cultural shift to change attitudes amongst UK farmers. Trade, policy, the level of uncertainty and business structures were identified as the main external and internal factors affecting the opportunities and challenges the UK agriculture will face. Results of this study also indicate that the future success of the UK agriculture industry requires the right enabling environment facilitated by government.
\end{abstract}

Keywords: Brexit, Cooperatives, UK Agriculture, New Zealand, Mixed Methods 


\section{Introduction}

The impact of Brexit on the UK agriculture sector remains uncertain. Independent of whatever form it takes; change within the farming industry will be needed in order to ensure success. Experts have claimed that there is a need to improve productivity and resilience in UK agriculture, ensuring competitiveness in new markets and increasing the contribution of agriculture to the economic growth of the country (Whitfield \& Marshall, 2017).

Many parallels have been drawn between the experiences of New Zealand in the 1980s and what the UK agriculture sector might face after leaving the European Union. Unlike the farming industry in New Zealand, UK farmers will have time to plan for changes. In spite of the differences, lessons can be learnt from the reaction of the New Zealand agricultural industry to the changes they experienced which saw, after a period of adjustment, an increase in productivity. One significant difference between New Zealand and the United Kingdom is the extent to which cooperation is embedded into the agricultural industry. New Zealand was voted the most cooperative country in 2012 and certainly has a more embedded culture of cooperation within its agricultural industry in comparison with the UK (Garnevska, Callagher, Apparao, Shadbolt, \& Siedlock, 2017).

The specific objectives of this study are as follow:

- First, to identify opportunities and challenges facing UK agriculture in the post-Brexit era; and

- Second to assess the applicability of the New Zealand cooperative business model to the postBrexit agriculture sector in the UK. With this understanding, this research aims to help stakeholders within the agriculture sector to identify strategies to help the agriculture sector to remain productive, resilient and competitive in a challenging environment.

A highly productive agricultural industry is one, which ensures its long-term ability to compete in and grow new markets. Productivity is defined as "a measure of the rate at which we convert inputs into outputs." This highlights the fact that productivity is not about how much is produced but how efficiently it is produced (AHDB, 2018).

The Agricultural Horticultural Development Board (2018) report highlights that productivity growth in UK agriculture and horticulture has not kept up with other major competitors. The rate of productivity growth seen in the UK averages $0.9 \%$ each year while the Netherlands, for example, has achieved a 3.5\% growth each year. Many countries outside the EU are also performing better than the UK. For example, the USA with a growth of 3.2\% per year. Figure one shows the Total Factor Productivity (TFP) annual growth between 1964 and 2014. It is clear that productivity growth has been a problem for the UK agriculture issue. This issue will have to be addressed in order for the agricultural industry to thrive in a post-Brexit marketplace. 
INTERNATIONAL JOURNAL OF ACADEMIC RESEARCH IN BUSINESS AND SOCIAL SCIENCES Vol. 10, No. 2, Feb, 2020, E-ISSN: 2222-6990 @ 2020 HRMARS

Figure 1: Total Factor Productivity annual growth between 1964 and 2014

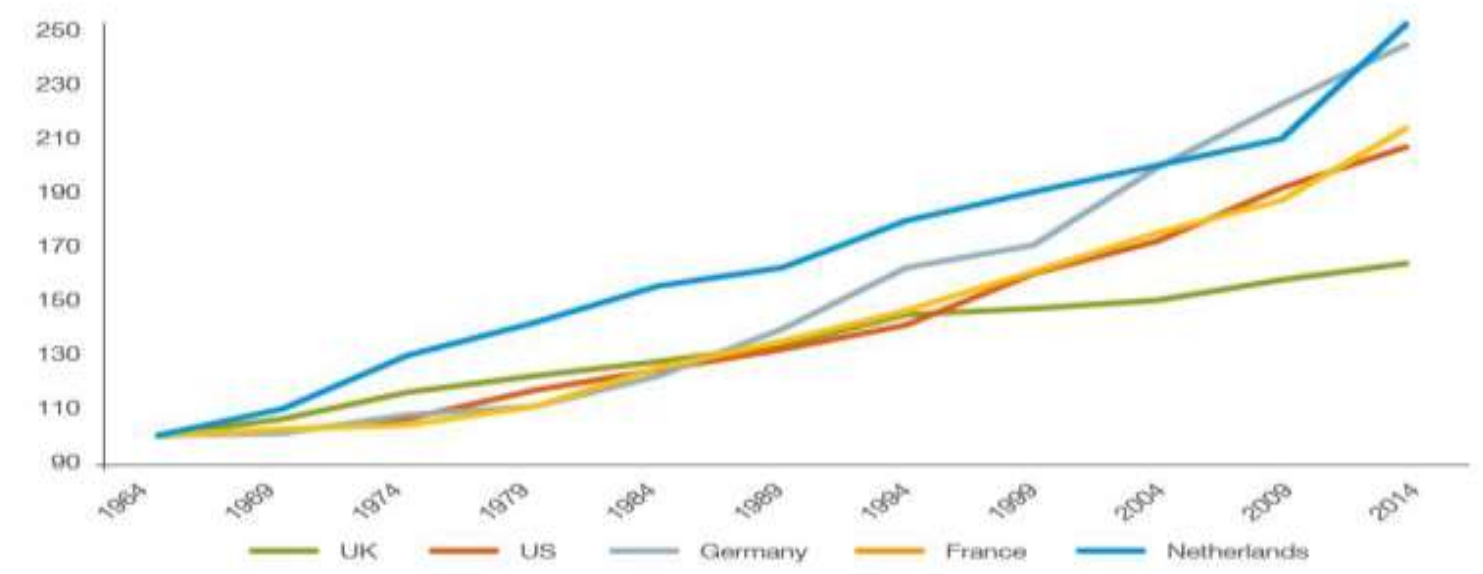

Source: (AHDB 2018)

Resilience is defined as "the capacity to recover quickly from difficulties". In the rapidly changing environment that the UK agricultural industry is about to experience the ability to recover quickly will be crucial (Berkum, Jongeneel, Vrolijk, van Leeuwen, \& Jager, 2016). For the UK agricultural industry to be resilient, it will need to focus not only on productivity growth but on the structures, it has in place to act as one body in the best interests of the agricultural industry as a whole.

Cooperatives take many forms but the philosophy underpinning these organizations is that all of them operate for the benefit of their members. Members own the cooperative and are involved in the control of its business. There are two main types of cooperative structure. Traditional cooperative structures and New Generation Cooperatives (NGCs). In traditional cooperatives all shares are owned by members, each member has one vote and all earnings are distributed to members and no parties are excluded from membership (Nillson, 1996). NGCs share many of the same attributes as traditional cooperatives but differ on some key issues. NGCs can restrict membership to specific types of shareholders and despite still operating on a one-member one-vote principle, they can also allow individual members to hold high levels of equity through the purchase of more shares (Bokenfohr, 2006).

\section{Agricultural Cooperation in the UK}

Agricultural cooperatives in the UK have had a chequered history since the $19^{\text {th }}$ century when the first official agricultural cooperative was set up. The numbers of agricultural cooperatives in the UK has fluctuated since this point increasing from around 30 cooperatives in 1892 to around 380 cooperatives in 1920 . The number of cooperatives then dropped by $40 \%$ in the 10 -year period leading up to 1930 and continued to decline over the next three decades (Eastham, 2012).

Empson (1998) looked at the history of the Milk Marketing Board, described as the greatest commercial enterprise ever launched by British farmers, reporting that it served the industry for sixty years until its demise in 1994 due to pressure from the EU regulatory framework and as a result of political demands for greater competition. This perhaps indicates that cultural issues of cooperation are overstated and that given the right legal environment cooperatives could thrive in the UK again. In the UK, cooperation was brought to modern attention by the Policy Commission on the Future of Food and Farming (2002). Written in the wake of the 2001 Foot and Mouth disease crisis, the Policy 
Commission set out as part of its vision for farmers to use cooperation to obtain better returns for their businesses. It identified that the results of collaborative efforts in the UK had been mixed but recommended the establishment of an English Collaborative Board responsible for encouraging and supporting collaborative activity. This was launched as the English Food and Farming Partnerships (EFFP), a Government sponsored initiative which is now an independent consultancy. However, it has been concluded that "whilst membership of cooperatives has increased since the establishment of the EFFP, there is little evidence as to the value of cooperatives as a means of halting the decline of the UK agricultural sector" (Eastham, 2012). Eastham (2012) goes on to look at issues of governance and decision-making within UK cooperatives. The gaps in the literature identified by Eastham have been used to inform the structure of the interviews for this research.

Industry experts claim that the UK agricultural industry should seek to work cooperatively and speak with one voice to achieve a favourable policy for the sector in the post Brexit era. The Chief Executive of Dairy UK supports this. She stated that there is a need for a good trade deal, access to labour and specific support for productivity growth (Dairy Industry International, 2017). She also mentioned that further vertical integration, perhaps through cooperation, should be a consideration for UK agriculture.

Vertical integration is the most difficult form of cooperation given the challenges of ensuring respect for the democratic principle. This can be overcome given good forms of governance. Kalogeras, Pennings, Benos, and Doumpos (2013) looks at how this can be achieved by allowing more of the concepts employed in investor owned firms to be used within cooperative structures to allow the best of both worlds to operate.

Cornforth (2004) suggests that there is no single blueprint for success within a cooperative and much will depend upon the contextual factors involved such as organisation size, public policy and societal expectations. This underlines the need to ensure that governance structures are built in a bespoke way for cooperatives to be successful. The conclusions of this research also underlines the need for a favourable legislative environment, which clearly was not the case at the time of the demise of the UK Milk Marketing Board. The post Brexit environment may provide a better framework for this type of approach.

One key area of change will need to be in how the industry uses collaboration and cooperation to the benefit of all involved in the food and farming supply chains. The UK has not utilised the cooperative model in the same way that others within the European Union (EU) have. In fact, the UK is ranked $23^{\text {rd }}$ out of the EU $27^{\text {th }}$ for cooperative market share. Although this is perhaps not because of a lack of cooperatives or cooperative membership, but a lack of engagement. Data gathered by Cogeca (2014) shows that the total number of cooperatives and the total number of members in the UK is not low in comparison to the majority of the EU but the UK is well behind the top players including France and Germany with regards to turnover.

\section{Possible Impact of Brexit on UK Agriculture}

The UK voted to leave the European Union on the 23 June 2016 and formal negotiations commenced when the UK Government notified the EU of its intention to end its membership of the European Union by triggering of article 50 of the Lisbon Treaty in March 2017.

The Common Agricultural Policy (CAP) that had previously played a central role in supporting UK agriculture will no longer apply to UK farmers. In its place, a new agricultural policy for the United 
Kingdom will be required. Leaving the European Union and in turn the Common Agricultural Policy will fundamentally affect the agricultural sector, primarily because in terms of trade the EU is the single largest trading partner in agri-food products that the UK has (Department of Food and Rural Affairs, 2018).

A report from the House of Lords European Union Committee (2017) based on a wide range of stakeholders highlights that substantial change is likely to face the farming industry in the post Brexit era. The report focuses mainly on what the UK Government will need to do in order to assist the farming industry deal with the consequences of Brexit. The government will need to ensure that the industry can establish trading agreements with the EU and the rest of the world in order to provide stability and confidence into the industry. However, the report provides very little by way of commentary on what the farming industry itself should be doing to respond to the challenges which lie ahead.

A report from the Worshipful Company of Farmers (Buckwell, 2016) anticipates that UK agriculture will face a number of "shocks" in the post Brexit era. It makes a specific comparison with the shocks experienced by New Zealand farmers in the 1980s following the overnight withdrawal of subsidies. The report argues that both the market and farmers would eventually adjust to the new scenario and that Brexit should be seen as a "catalyst for change". However, the report does caution about having a direct comparison made with the New Zealand situation due to the major structural differences between the UK and New Zealand. One of the differences highlighted is the extent to which the New Zealand agricultural industry operates within a more cooperative structure than in the UK.

Lang and Schoen (2016) take the view that even before Brexit the food systems of developed countries displayed fragility and vulnerability as seen through the financial crisis of 2007 and 2008, which saw major increases in commodity and food prices. It concludes that for the UK, Brexit will exacerbate this vulnerability and lead to a reduction in resilience, which the Government will need to address in the form of policies for food security, environmental delivery and the provision of wider social goals. As seen previously, there appears to be a reliance upon the need for public policy change rather than looking at what change could be enacted from the industry itself.

If the Common Agricultural Policy is left behind, a new statutory framework has been suggested that will allow the Government to "set out a dynamic policy that will stand the test of time. The report provides some details about what the Government wants to achieve in terms of outcomes and puts great emphasis on the transition period away from the Common Agricultural Policy (DEFRA, 2018). What the proposal omits is a clear view of how the proposed outcomes are going to be achieved in reality. However, it does look at some of the challenges and opportunities arising from Brexit, the need for improvement in productivity and the role that cooperation and collaboration might play in achieving that.

\section{Cooperation in New Zealand}

Cooperation has been an important component of New Zealand agriculture for a very long time, particularly in the dairy sector. However, until the subsidies were removed many farmers were less inclined to consider cooperation as a way forward. It is interesting to note that, New Zealand has a flexible legislative environment, which has assisted cooperative growth and development. This has allowed cooperatives in New Zealand to adapt and respond to changing market conditions. The cooperative movement has been unconstrained by what the researchers' term "slavish adherence" 
to traditional cooperative models. Although cooperative governance is often seen as inferior to the governance structures within investor owned firms (IOF) the fact that cooperatives have shared vision and mutual interest can provide a strong platform for concerted growth within a cooperative system. Not surprisingly, the implementation of cooperatives have not been without challenges. There have been issues of individuals' free riding on the market conditions created by the cooperative; issues of governance; and issues around investor confidence (Evans \& Meade 2016). A literature review on the performance of cooperative organisations in comparison to investor owner firms shows contradicting views. While some scholars claim that cooperative organisations perform better and are more resilient than investor owner firms, other scholars suggest the opposite (Nilsson, Kyriakopoulos \& Meulenberg, 2004; Bijman \& Ilpopoulos, 2014; Reddy \& Locke, 2014).

Mullen (2010) reports that in New Zealand, since the 1990s, productivity growth in agriculture has outstripped productivity growth in the wider New Zealand economy. This is in contrast to the situation in the UK where productivity in UK agriculture has flat lined and in recent years declined (Thirtle, Holding, Jenkins \& Piesse, 2004). Interestingly, Hall and Scobie (2006) claim that productivity growth in the New Zealand agricultural economy is largely a result of the availability of the output of research and development. However, freely available international research and development appears to be more important than that which was generated domestically. Given that the UK would have had similar access to such research and development knowledge, it does not explain why there has been a difference in productivity between the two nations. Could it be down to the extent to which there is cooperation in the agricultural industries of the two nations?

\section{Methodology}

The pragmatism research philosophy was adopted as the dominant paradigm to meet the research objectives outlined above. The mixed methods research approach was considered the most suitable approach for the purpose of this research.

Semi-structured interviews were conducted with key players within the agricultural industry in the UK and New Zealand. A purposeful and convenience sampling method was deemed the most appropriate non-probability sampling method to address the objectives of this research. The criterion used for selecting interviewees was that they have been involved in the decision making process of strategic decisions for agribusiness companies in the UK and New Zealand. In depth personal interviews were conducted with: NFU President; AHDB Chief Strategy Officer; Co-operatives UK Agriculture Manager; Chairman of UK Federation of Milk Groups 1998 to 2000; Chairman of Milk Marque 1997-2000; Oxford Farming Conference Director; Divisional Director at Promar International Ltd; CEO at Cooperative Business New Zealand; and New Zealand Cooperative Director.

All interviews were conducted during 2018 and lasted approximately one hour and a half. The interviews were recorded using Sonocent Audio Notetaker with transcripts produced from the recordings. The appropriate procedures were followed with regards to confidentiality and consent to be recorded. All interviewees were asked for permission to record the conversation and permission to be named and quoted within the findings of the report.

An online questionnaire was produced following the outcomes of the semi-structured interviews with key players within the agricultural industry. The results of the questionnaire were used to support data gathered from the structured interviews. The questionnaire was distributed using Twitter. 813 farmers completed the survey. 
INTERNATIONAL JOURNAL OF ACADEMIC RESEARCH IN BUSINESS AND SOCIAL SCIENCES Vol. 10, No. 2, Feb, 2020, E-ISSN: 2222-6990 @ 2020 HRMARS

The structured interviews were analysed using NVivo. The questionnaire responses were analysed using the built in analysis software within BOS surveys. The software allowed the cross tabulation of answers to questions in order to identify correlations within results received.

\section{Research Findings}

The interviewees were asked to share their thoughts and opinions about the challenges and opportunities facing UK agriculture post Brexit.

Industry experts expressed the greatest amount of concern around issues associated with trade. In fact, all of the interviewees from the UK highlighted trade issues as a significant challenge facing the UK agricultural industry.

Respondent 1 described trade as a big unknown because we don't know what the future trading relationship will be between the EU and the UK. Respondent 4 also suggested that on a much wider scale the biggest challenge is the uncertainty.

The importance of continuing trade with the European Union was echoed throughout many of the interviews.

Respondent 6 highlighted the fact that currently 65\% of our exports go to Europe.

Increased competition was another concern mentioned within discussions around trade. Most interviewees believe that there is potential for domestic producers to be exposed to more international competition.

Respondent 7 mentioned that a move to a more liberal trade can lead to a reduction of prices. This will challenge individual businesses particularly in relation to commodity products.

Five of the seven industry experts identified a change in policy direction following Brexit as a potential challenge for the agricultural industry. The majority of concerns centred on the level of support received by farmers.

Respondent 5 highlighted that the British farming industry has been heavily dependent on the CAP for income.

Most of the respondents mentioned that the farming industry is likely to receive far less support from Government. The government will have to assess how to allocate resources among different sectors and the long-term future of pillar one payments are suspect. Reduced direct payments would affect the profitability and future success of many firms.

Industry structured was identified by 4 interviewees as another important challenge for UK agriculture post Brexit.

Respondent 3 suggested that the UK was a very fragmented country with very old ways of doing things. Respondent 6 also pointed that the UK infrastructure and small field sizes has made it difficult to compete with other countries particularly when it comes to commodity products.

Nearly all interviewees agreed that a fragmented supply chain and a culture of individual trading would not help to compete in a global market. The findings reveal that most respondents believe that structural change and consolidation are prerequisites to compete under existing World Trade Organization agreements.

Constraints on labour supply was identified as a challenge for the agricultural industry after Brexit by two interviewees. Respondent 3 commented that labour supply has been a problem for the last 10 years in the UK and that Brexit may make a difficult situation even worse. Respondent 4 stated that in the long run everybody thinks the cost of labour would rise anyway, therefore we will have to invest 
INTERNATIONAL JOURNAL OF ACADEMIC RESEARCH IN BUSINESS AND SOCIAL SCIENCES Vol. 10, No. 2, Feb, 2020, E-ISSN: 2222-6990 @ 2020 HRMARS

in automation to reduce dependency on labour and suggested that perhaps the Brexit process will hasten the natural transition.

Plant and animal health status was another theme identified by several interviewees. Respondent 7 claimed that as a country the UK "really needs to clean up [its] act on disease" she gave the example that there is still currently no BVD (Bovine Viral Diarrhoea) programme in the UK which she said was "outrageous" and suggested that the UK needs to create "better disease outcomes". Respondent 2 highlighted the continuing demand for higher integrity products and suggested that it would only become "more pronounced" as time goes on. This demand for higher integrity products, along with the need to protect the environment and maintain good public perceptions, also leads to increased pressures on the amount of inputs available.

The majority of respondents agreed that competition for land and resources will be a big challenge for the UK agriculture industry post Brexit.

The findings revealed that productivity is an issue for UK agriculture. For example, respondent 2 mentioned that it's not just a current weakness it's a long-term weakness, our productivity has been relatively flat for the last 15 years and we are losing ground to our major competitors.

Nearly all interviewees agreed that there is a need for more relevant research and development, innovation and better coordinated technology transfer within the agricultural industry. Respondent 1 stated that as an industry "we haven't embraced technology" and that there has been "a systematic cut to research and development funding in the UK" and wondered why the industry was surprised at its lack of productivity growth.

The view that the way knowledge is shared within the industry is fragmented was common throughout the interviewees. Many suggested that there needed to be a more coordinated approach to filtering down information learnt by research institutions and companies in order for it to have a positive effect on the productivity of individual farms. There were several suggestions from interviewees that extension services such as ADAS (when they were part of the Ministry of Agriculture as an in-house advisory team) were beneficial to creating a more targeted joined up approach to R\&D and that perhaps something is needed now to fill this gap. Responded 5 said that first the industry needs to make sure that research institutions are doing research that actually benefits and is applicable and relevant to farmers.

Findings suggest that the industry needed to focus more on skills and training in order to improve productivity. Also, that the CAP and direct payments have held back business progression, development and innovation. Although many did agree that direct payments have not aided productivity growth, there were some that did not think they were to blame for the UK's lack of productivity growth. Respondent 3 mentioned that Germany, France and Holland were doing really well out of the system and improving their productivity. There was a feeling that whatever system of support or business structure is used that it should not be shielding poor performers.

From interviewing the industry experts, it was clear to see that the history of cooperation in the UK is a barrier to further cooperation. Respondent 7 commented that compared to other countries we are not very good at cooperating. The respondent went as far to say that she thought "it is a real weakness and I think it's something that has become endemic in the UK.

There are many complicated reasons as to why the general consensus is that cooperatives have not been very successful in the UK. The memory of poor track records and farmers having to pick up the financial costs when things go wrong with cooperative failures appears to have had an effect on the 
INTERNATIONAL JOURNAL OF ACADEMIC RESEARCH IN BUSINESS AND SOCIAL SCIENCES Vol. 10, No. 2, Feb, 2020, E-ISSN: 2222-6990 @ 2020 HRMARS

willingness of individuals to cooperate. The research suggests that there is a large cultural issue with cooperation within the UK. Many agreed that there was an "individualism" attitude amongst UK farmers. Respondent 4 claimed that there is an individualistic mind-set amongst farmers and amongst British society as a whole.

Poor governance and management were identified as reasons for cooperative failure and perhaps a barrier to future success of cooperatives. Concern was also shared around the conflict between meeting the customer's needs and the members' needs and how it was important to balance the two.

Three respondents talked about the importance of cooperative engagement and how "actively involved" people are within the cooperatives of which they are members. Respondent 6 suggested that part of the problem in the UK is that "there are a lot of farmers that would tend to look at a cooperative as just another supplier and don't see the difference".

The majority of respondents suggested that there had been a lack of joined up thinking from Government and inconsistent policies or support provided.

This research suggests that there are many different types of cooperation that can operate on an informal or formal basis. Respondent 1 highlighted the success of Mole Valley Farmers which he said "isn't a cooperative but it is a farmer owned business". Marketing appears to be key when it comes to a successful cooperative.

Formal cooperatives have many benefits and the majority of respondents were keen to express the potential cooperatives have to strengthen the UK agricultural industry. Respondent 5 said that "the two principles that work very well are sharing all the information and everybody constantly trying to improve".

Respondent 7 went further than just saying cooperatives benefit their members. She referenced $a$ couple of reports that said "that if you support farmer cooperatives it helps the bottom line of all farmers not just farmers who are involved in cooperatives."

Cooperatives can also assist with knowledge exchange and help to improve supply chain integration within the agricultural industry. Cooperatives are in a good position to ensure their members get the best value from purchases in addition to adding and creating value within the supply chain and retaining it for the good of the agricultural industry. Respondent 2 emphasized on the fact that cooperatives could add value within the supply chain. He gave the example of machinery rings and said that "one of the reasons we are less competitive than we could be in cereal production is ... too many arable farmers have got high fixed costs ... they are spending too much money on machinery so if you could better utilise machinery through a machinery ring... presumably reduce your fixed costs". Six interviewees suggested that one of the benefits of cooperatives was the fact that they are often more stable than investor owned firms. Many of the industry experts identified successful UK cooperatives such as OMSCo, Berry Gardens, Arla, Camgrain, Openfield, Nene potatoes and Anglia Farmers. They praised them for their focus on the market and their ability to provide resilience and protection from volatility to their members.

The interviewees were asked to share their thoughts about the opportunities for the agricultural industry post Brexit. The table below shows the answers given by the interviewees grouped by theme.

Table 1: Opportunities post Brexit 
INTERNATIONAL JOURNAL OF ACADEMIC RESEARCH IN BUSINESS AND SOCIAL SCIENCES Vol. 10, No. 2, Feb, 2020, E-ISSN: 2222-6990 @ 2020 HRMARS

\begin{tabular}{|l|l|c|c|c|c|c|}
\hline & $\begin{array}{l}\text { Better } \\
\text { regulation }\end{array}$ & $\begin{array}{l}\text { New } \\
\text { trade } \\
\text { deals }\end{array}$ & $\begin{array}{l}\text { Control } \\
\text { over policy }\end{array}$ & $\begin{array}{l}\text { Import } \\
\text { substitution }\end{array}$ & $\begin{array}{l}\text { Innovation/business } \\
\text { development }\end{array}$ & Collaboration \\
\hline Respondent 1 & $\mathrm{X}$ & $\mathrm{X}$ & $\mathrm{X}$ & & & \\
\hline Respondent 2 & & $\mathrm{X}$ & & $\mathrm{X}$ & & \\
\hline Respondent 3 & & $\mathrm{X}$ & $\mathrm{X}$ & $\mathrm{X}$ & $\mathrm{X}$ & \\
\hline Respondent 4 & & & $\mathrm{X}$ & $\mathrm{X}$ & & \\
\hline Respondent 5 & & $\mathrm{X}$ & & & $\mathrm{X}$ & \\
\hline Respondent 6 & & $\mathrm{X}$ & $\mathrm{X}$ & & $\mathrm{X}$ & $\mathrm{X}$ \\
\hline Respondent 7 & & $\mathrm{X}$ & & & $\mathrm{X}$ & 1 \\
\hline Total & 1 & 6 & 4 & 3 & 4 & \\
\hline
\end{tabular}

The answers given by the industry experts when asked to name the top three challenges and the top three opportunities for UK agriculture post Brexit were consistent throughout. Every answer was able to be grouped into one of six themes with widespread agreement across the most common answers for both the opportunities and the challenges. Interestingly, trade was identified as the main challenge and opportunity for UK agriculture post Brexit. Similarly, the change in direction of policy was again mentioned as both an opportunity and a challenge by a large proportion of the interviewees. What was also common throughout both the opportunities and challenges section was the amount of uncertainty felt by the majority of the industry experts.

Only one respondent mentioned the opportunities that increased cooperation may bring. Perhaps this indicates a broader concern about the operating environment to enable the success of all businesses, cooperatives or not. At the time the industry experts were interviewed, the environment in which the industry will operate after Brexit was unknown, meaning that the interviewees' primary concern was perhaps ensuring the correct enabling environment can be produced to build a foundation on which all successful businesses can operate rather than looking at one particular model for how this might be achieved.

\section{Results of Online Farmer Questionnaire}

From the interviews with the industry experts, it became clear that the attitude of those operating within the UK agricultural industry may be a barrier to further cooperation. In order to assess the feeling of those actively farming an online questionnaire was conducted of 813 farmers as explained in the methodology. 
Figure 2: Main Farm Type

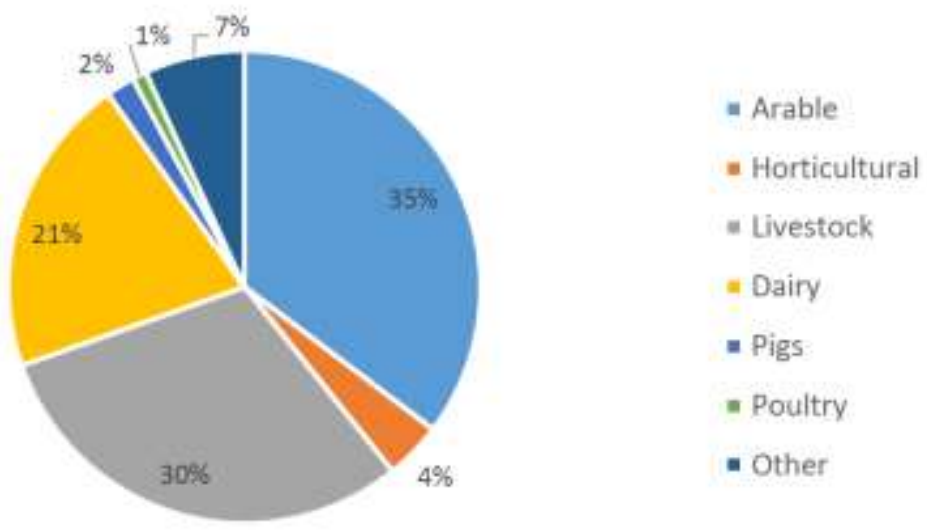

When compared to The Farm Business Survey conducted in 2016/ 2017 by National Statistics on behalf of the Department for Environment Food and Rural Affairs the span of farm types seen within the responses to the survey match extremely well (National Statistics, 2017).

$65 \%$ of respondents said they had been involved in some form of cooperative or collaborative activity. This would include both formal and informal forms of cooperation. This figure is slightly higher than the conclusion of the work by Cooperatives UK in its study into cooperative membership in the UK. It estimated a figure of 155,000 farmers which it said was approximately half of the UK's farmers (Self, 2017). However, this survey was self-selecting and shared using Twitter. Those who answered the survey were aware of the subject area before choosing to start the survey. Also the sample may not be from a representative group of individuals perhaps because those farmers on Twitter are already more engaged and collaborative than farmers not involved in social media.

Cross tabulation was used to assess whether there were trends in the data with regards to the farm type and size in comparison to involvement with cooperative and collaborative activity.

Figure 3: Farm size in acres against involvement in cooperatives or collaborative activity

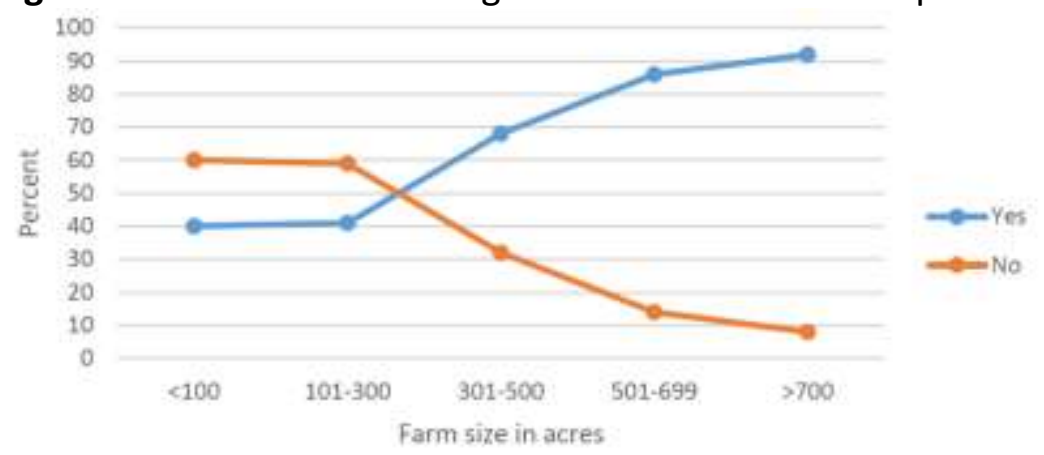

It was interesting to observe that more of the larger farms were acting cooperatively than the smaller farms. Assumptions could have been made that small farms would need to have cooperated more in order to be able to compete with larger businesses. The results from this survey contradict this assumption. 
INTERNATIONAL JOURNAL OF ACADEMIC RESEARCH IN BUSINESS AND SOCIAL SCIENCES Vol. 10, No. 2, Feb, 2020, E-ISSN: 2222-6990 @ 2020 HRMARS

Figure 4: Farm type versus involvement in cooperative or collaborative activity

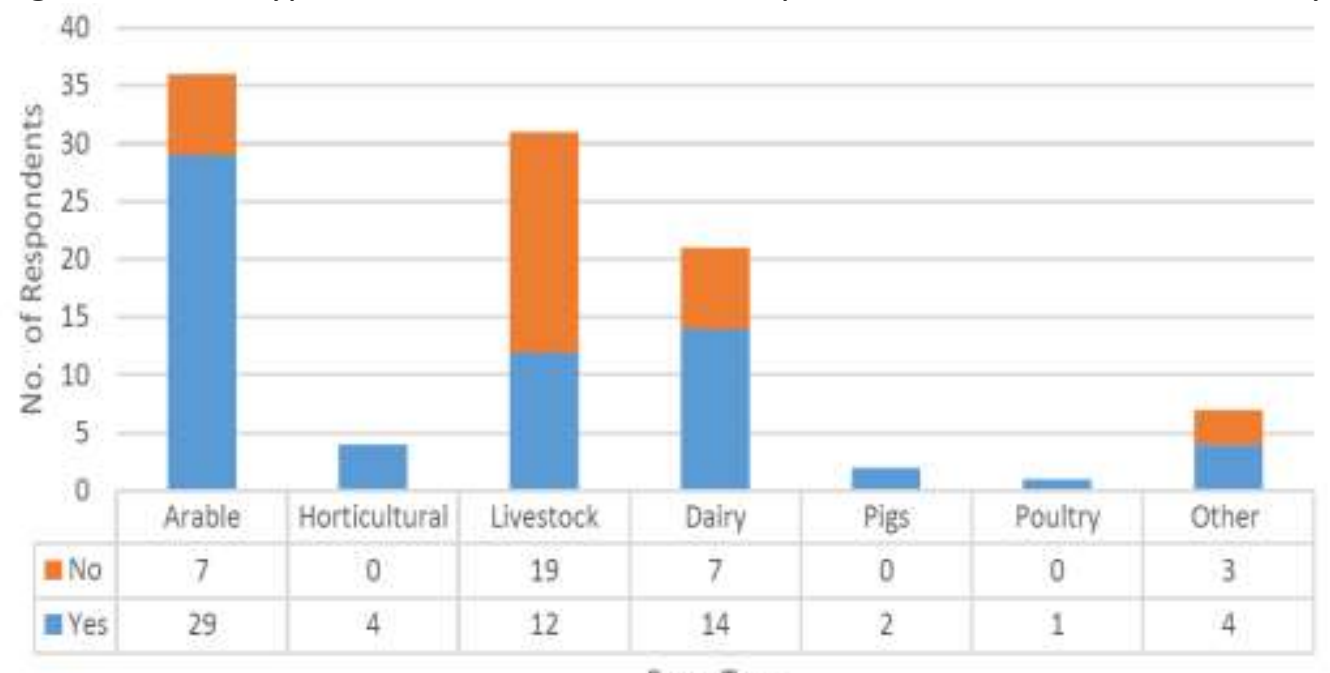

Farm Type

\section{Yes $\|$ No}

As seen in figure 4, across most farm types the majority of respondents reported involvement in cooperative or collaborative activity. The only farm type where this was not the case was on livestock farms where $61 \%$ of respondents said that they had not been involved in any form of cooperative or collaborative activity. This does support what interviewees had been saying about the livestock industry and the apparent unwillingness to cooperate and collaborate. This also mirrors the situation seen in New Zealand immediately after support for farmers was removed in the 1980's. In New Zealand it took livestock farmers much longer to form cooperatives and work together and therefore the sector struggled to keep up with the highly cooperative dairy industry. Since then cooperatives in the red meat sector in New Zealand have grown and now the two biggest red meat exporters in New Zealand are cooperatives. This could be a lesson for the UK experience after Brexit as the level of long-term support from the Government is still unknown.

$95 \%$ of respondents who were involved in cooperative or collaborative activity said that their involvement with cooperative or collaborative activity was either beneficial or very beneficial to their business. This shows that when involved in cooperation or collaboration, the vast majority of respondents in the survey showed positive attitude towards them whether they were more formal types of cooperation or less formal forms of collaboration.

The majority of respondents (92\%) agreed or strongly agreed that British agriculture would be more resilient if farmers acted more cooperatively or collaboratively. Farmers were further asked to express their thoughts about those elements of cooperatives that would be the most beneficial to the resilience of UK agriculture. Cooperative marketing, cooperative purchasing and cooperative knowledge exchange were the top three answers given and between them they were selected by $73 \%$ of respondents. This is in line with the conclusions drawn by the industry experts interviewed from the UK. Respondents also mentioned that in order to improve the resilience of British agriculture there is an opportunity for improving UK farm productivity and efficiency by utilising technology and becoming more market focused. 
INTERNATIONAL JOURNAL OF ACADEMIC RESEARCH IN BUSINESS AND SOCIAL SCIENCES Vol. 10, No. 2, Feb, 2020, E-ISSN: 2222-6990 @ 2020 HRMARS

Out of the $5 \%$ of respondents that thought that acting more cooperatively and collaboratively would not benefit the UK agricultural industry $43 \%$ gave one of their reasons for holding this opinion as 'concerns about poor management of cooperatives'.

Most of the respondents mentioned that in times of difficulty cooperatives may in fact show greater resilience because the members are invested in the business and want it to survive in the long term. This long-term view is something that suppliers of investor owned businesses do not have.

\section{Semi-Structured Interviews with New Zealand Experts}

Interviewee 8 mentioned that the amount of cooperative dominance within New Zealand is a contributing factor to the success of New Zealand agriculture and the wider economy. "I believe one of the main reasons these cooperatives lead to such great success is their ability to assist with the resilience, profitability and productivity of the agricultural industry".

Interviewee 9 claimed that "New Zealand trusted the cooperative business model far greater than investor owned companies that could be here today and gone tomorrow".

Nearly all interviewees agreed that to compensate for New Zealand location farmers have had to become more innovative and collaborative. The research further explored what mechanisms were used to encourage cooperative loyalty and engagement to add to the deep-rooted sense of cooperative spirit. Interviewee 9 mentioned that "in the end it's down to control and ownership and no outside investors - no foreign investments... it was important that profits were retained locally".

Findings indicate that cooperatives that start out with the right intentions will encourage greater levels of engagement and loyalty if their values and vision are centred around strong cooperative principles. Interviewee 8 stated that "as cooperatives get bigger it is difficult to maintain the same levels of engagement".

Cooperatives in New Zealand have been successful in spite of cooperatives not receiving support from the government. However, interviewees highlighted the minimal red tape to set up a cooperative. Respondents also mentioned the importance of alignment with the UN sustainable development goals (SDG's) and highlighted the similarities between them and the cooperative principles.

\section{Conclusions}

The change in circumstances that New Zealand experienced in the 1980s did drive greater cooperation within the agricultural industry. There are many lessons to be learnt from the reaction of the agricultural industry within New Zealand despite the fact that direct comparisons cannot be made. The agricultural industry pulled together and reacted to changes in market forces. The cooperatives at the time had a longer-term view than many investors owned businesses and were therefore able to survive and thrive. Now the agricultural industry is dominated by cooperatives, which adds great strength to their sector. The amount of cooperative engagement and economic participation seen from farmers is far greater than is seen in the UK.

Productivity has been a long-term issue for UK agriculture. Fragmentation in R\&D, innovation and knowledge exchange are responsible for UK farm productivity lagging behind major competitors. An increased amount of collaboration within this area would lead to more specific, relevant research and development, innovation and knowledge exchange taking place within the industry. When properly governed and focused on the market with a loyal membership base, cooperatives have the 
potential to add great strength to the agricultural industry by adding and retaining value within the supply chain.

Results from interviewees suggest that there was an individualistic attitude amongst UK farmers. The attitudes of individuals will be difficult to change and it may take a considerable amount of time to change the opinion of traditional farmers. However, results from the survey show a shift in attitude and that individuals are starting to see the benefits of wider collaboration and cooperation within the agricultural industry. It is not just formal cooperatives that can make a difference within the industry. Informal cooperation focusing on greater collaboration, particularly with regards to knowledge exchange, will ultimately help improve productivity and resilience in UK agriculture.

While there are good examples of cooperatives in New Zealand, there are also some good examples in the UK. These successful UK cooperatives have shown great focus on market changes and have remained agile to keep pace with their changing environments.

Applying any lessons learned to the agricultural industry in the UK will be the most important step when aiming to improve productivity and resilience in UK agriculture. Where cooperatives are able to help improve businesses they should be encouraged and facilitated to do so. The Government should perhaps consider increasing its support for the development of cooperatives through a facilitation fund or program. A $£ 10$ million collaboration fund was announced in February 2018 to help bring greater cooperation within the industry. It will, however, be important that this fund is used to facilitate cooperatives to become independent successful businesses that are not reliant on funding or Government support. This fund should be implemented alongside a network of supportive structures that can enable continued success rather than just financial incentives.

Where cooperatives are formed they will need to ensure their members are fully engaged and utilising the cooperative to its full potential, rather than just treating it as another buyer. It is clear that cooperative engagement is an important aspect to consider because of the obvious benefits of increased throughput of produce through cooperatives. Not only can cooperatives add and retain value within the agricultural industry but they will also have a positive effect on all farmers not only those that are members.

Trade was identified by all of the interviewees as being a significant challenge for UK agriculture in the post Brexit era. Competing within the global marketplace will be challenging enough as a small country so it is important that individual businesses work together to put themselves in the strongest most productive and resilient position possible. This is not only the case for individual farming businesses but for those organisations responsible for representing the industry.

\section{Contributions}

An understanding of what causes some industries to be more competitive than others is essential for effective policy prescriptions and business decisions.

In this paper, we report on the business challenges that the UK agriculture sector will face after Brexit. This is significant because there is uncertainty about policy development to replace the Common Agricultural Policy.

It is believed that the present study makes a contribution in assessing the applicability of the New Zealand cooperative business model to the post-Brexit agriculture sector in the UK. There is no 
INTERNATIONAL JOURNAL OF ACADEMIC RESEARCH IN BUSINESS AND SOCIAL SCIENCES Vol. 10, No. 2, Feb, 2020, E-ISSN: 2222-6990 @ 2020 HRMARS

previous work that has critically evaluated the applicability of the New Zealand cooperative business model in the UK after Brexit.

This paper also makes an empirical contribution. Qualitative and quantitative analysis shows that Brexit represents a potential threat for the UK agricultural sector. To mitigate this threat, this research has also contributed with a package of recommendations that would help UK farmers to be prepared to compete in a new challenging environment.

\section{Areas for Further Research}

There are several areas of further research that would benefit the UK agricultural industry. Identifying which parts of UK agriculture would be best suited to higher levels of cooperation is one area where focus could be placed. This would allow for a more targeted approach to encouraging and facilitating greater cooperation and collaboration. It may also provide some models that would be best suited to different sectors within the agricultural industry. Further research could take place to look at how cooperative and collaborative activity can be encouraged within the livestock sector in order to ensure it does not fall behind in terms of levels of cooperation and overall productivity and resilience. In addition to this, further research could be undertaken looking at how it might be best for new and existing cooperatives to be facilitated. This area of research could look at some of the more successful cooperatives in the UK as well as within Europe and New Zealand to see how they could have been best supported when they were first started. This would perhaps give a framework or direction of travel for any facilitation fund or activity that may take place.

\section{References}

Agricultural Horticultural Development Board. (2018). Driving productivity together. Retrieved from https://ahdb.org.uk/documents/Horizon Driving\%20Productivity_Jan2018.pdf

Berkum, S. Van., R. A. Jongeneel, H. C. J., Vrolijk, M. G. A., Van Leeuwen., \& Jager, J. H. (2016). Implications of a UK exit from the EU for British agriculture. Study for the National Farmers' Union (NFU), Warwickshire, UK.

Bijman, J., \& Iliopoulos, C. (2014). Farmers Cooperatives in the EU: Policies, Strategies, and Organisation. Annals of public and cooperative economy, 84(4), 497-508.

Bokenfohr, J. (2006). New Generation Cooperatives-10 Things You Need to Know. Retrieved from www1.agric.gov.ab.ca/\$department/deptdocs.nsf/all/bmi6646

Buckwell, A. (2016). Agricultural implications of Brexit. Retrieved from: http://ca1fml.edcdn.com/downloads/WCF-Brexit-18.01.16-pdf.pdf?mtime=20160207094708

Cogeca. (2014). Development of Agricultural Cooperatives in the EU. Retrieved from http://agricultura.gencat.cat/web/.content/de_departament/de02_estadistiques_observato ris/27_butlletins/02_butlletins_nd/documents_nd/fitxers_estatics_nd/2015/0165_2015_IA _Cooperatives_Cooperatives-UE.pdf

Cornforth, C. (2004). The Governance of Cooperatives and Mutual Associations: A Paradox Prospective. Annals Public and Cooperative Economies, 75(1), 11-32.

Dairy Industries International. (2017). To Brexit and beyond. Dairy UK Annual Seminar. Bell Publishing Ltd. 
INTERNATIONAL JOURNAL OF ACADEMIC RESEARCH IN BUSINESS AND SOCIAL SCIENCES Vol. 10, No. 2, Feb, 2020, E-ISSN: 2222-6990 @ 2020 HRMARS

Department for Environment Food and Rural Affairs. (2018). Health and Harmony: the future of food, farming and the environment in a green Brexit. Retrieved from: https://www.gov.uk/government/consultations/the-future-for-food-farming-and-theenvironment.

Eastham, J. (2012). An analysis of the success of UK agricultural marketing co-operatives: can they effectively redress imbalances in current market conditions. University of Birmingham.

Empson, J. (1998). The History of the Milk Marketing Board, 1993-1994: British farmers' greatest commercial enterprise. International Journal of Dairy Technology. 51(3): 77-85

Evans, L., \& Meade, R. (2006). The Role and Significance of Co-Operatives in New Zealand Agriculture: a Comparative Institutional Analysis. New Zealand Institute for the study of competition and regulation.

Garnevska, E., Callagher, L., Apparao, M. D., Shadbolt, N., \& Siedlok, F. (2017). The New Zealand cooperative economy. Massey University, Palmerston North, New Zealand.

Hall, J., \& Scobie, G. (2006). The Role of R\&D in Productivity Growth: the Case of Agriculture in New Zealand: 1927 to 2001. New Zealand Treasury working paper. 6(1)

Kalogeras, N., Pennings, J., Benos, T., \& Doumpos, M. (2013). Which Cooperative Ownership Model Performs Better? A Financial-Decision Aid Approach. Agribusiness international Journal, 29(1), 80-95.

Lang, T., \& Schoen, V. (2016). Food the UK and the EU: Brexit or Bremain?. UK Food and Research Collaboration. City University of London.

Mullen, J. (2010). Agricultural Productivity Growth in Australia and New Zealand. The Shifting Patterns of Agricultural Production and Productivity Worldwide, (5), 102-122.

Nilsson, J. (1996). The Nature of Cooperative Values and Principles. Annals of Public and Cooperative Economies, 64(2), 633-653.

Nilsson, J., Kyriakopoulos, K., \& Meulenberg, M. (2004). The Impact of Cooperative Structure and Firm Culture on Market Orientation and Performance. Agribusiness international Journal, 20(4).

Reddy, K., \& Locke, S. (2014). The Relationship between Ownership Structure, Capital Structure and Corporate Government Practices. International Journal of Managerial Finance, 10(4), 511536.

Thirtle, C., Lin, L. Holding, J., Jenkins, L., \& Piesse, J. (2004). Explaining the Decline in UK Agricultural Productivity Growth. Journal of agricultural economics, 55(2), 343-366.

Whitfeild, S., \& Marshall, A. (2017). Defining and delivering sustainable agriculture in the UK after Brexit: interdisciplinary lessons from experiences of agricultural reform. International Journal of agricultural sustainability, 15(5), 501-513. 